\title{
PESANTREN DAN PEMBENTUKAN BUDAYA HUKUM ISLAM INDONESIA: PEMBARUAN LITERATUR FIKIH DI PESANTREN
}

\author{
Samsudin \\ Fakultas Syariah dan Ekonomi Islam \\ IAIN Syekh Nurjati Cirebon \\ Jl. Perjuangan By Pass Sunyaragi Cirebon \\ Email : Samsudin@yahoo.co.id
}

\begin{abstract}
Abastrak
Pesantren merupakan lembaga pendidikan Islam tertua di Indonesia yang telah berusia ratusan tahun. Hal ini merupakan kekayaan besar bagi bangsa Indonesia, karena tidak sedikit karya dan manfaat yang diberikan oleh institusi ini, Dalam konteks khazanah pemikiran fikih, pesantren juga sangat berperan dalam membangunan kultur hukum Islam di Indonesia. Tidak hanya bagi para santrinya, pesantren telah mampu mentransfer bidang keilmuan Islam ini kepada masyarakat yang ada di sekitarnya atau masyarakat Indonesia secara umum, sistem pembelarajan pesantren, terutama pesantren tradisional atau salaf, selama ini masih bersifat Syafi'i oriented, sehingga pemahaman hukum Islam yang seharusnya dapat lebih luas terlalu disimplifikasikan kepada satu pendapat saja. Perubahan kurikulum pembelajaran fikih ini dapat dimulai dari santri-santri senior yang telah memiliki cukup banyak amunisi untuk memahami fikih secara komprehensif. Selain telah memiliki dasar dalam menjalankan aktifitas keagamaan sehari-hari dari suatu mazhab tertentu, Dengan demikian, penting kiranya untuk membuka kotak pandora yang selama ini belum tersentuh,
\end{abstract}

Kata Kunci : Pesantren, Kitab Kuning, Hukum Islam

Pesantren is the oldest Islamic educational institution in Indonesia that has hundreds of years old. This is a great wealth for the Indonesian nation, because not a few works and benefits provided by this institution, In the context of the treasury of jurisprudence, pesantren is also very instrumental in developing the culture of Islamic law in Indonesia. Not only for the santri, pesantren has been able to transfer this field of Islamic scholarship to the surrounding community or Indonesian society in general, pesantren system pemarajan, especially traditional pesantren or salaf, so far still Syafi'i oriented, so that the understanding of Islamic law should be more broadly undermined to one opinion only. Changes in the jurisprudence curriculum can be started from senior santri students who already have enough ammunition to comprehensively comprehend fiqh. In addition to having a basis in running the daily religious activities of a particular school, Thus, it is important to open a box that has not been untouched pandora,

Keywords: : Pesantren, Kitab Kuning, Islamic Law 


\section{A. PEndahuluan}

Pesantren merupakan lembaga pendidikan Islam tertua di Indonesia yang telah berusia ratusan tahun. Hal ini merupakan kekayaan besar bagi bangsa Indonesia, karena tidak sedikit karya dan manfaat yang diberikan oleh institusi ini.

Dalam perkembangannya, pesantren banyak menghadapi tantangan seiring dengan majunya peradaban dan ilmu pengetahuan. Dari sini pula, sejumlah pesantren telah melakukan pembaruan dan pengembangan agar dapat menjawab problematika zaman tersebut. Secara praktis, pembaruan dan pengembangan ini telah dapat merespon kondisi kekinian masyarakat Indonesia, walaupun pada aspek tertentu perlu pula disempurnakan lagi untuk mendapatkan hasil yang maksimal.

Dalam konteks khazanah pemikiran fikih, pesantren juga sangat berperan dalam membangunan kultur hukum Islam di Indonesia. Tidak hanya bagi para santrinya, pesantren telah mampu mentransfer bidang keilmuan Islam ini kepada masyarakat yang ada di sekitarnya atau masyarakat Indonesia secara umum.

Namun demikian, sistem pembelarajan pesantren, terutama pesantren tradisional atau salaf, selama ini masih bersifat Syafi'i oriented, sehingga pemahaman hukum Islam yang seharusnya dapat lebih luas terlalu disimplifikasikan kepada satu pendapat saja. Lebih jauh lagi, pandangan yang hanya terpaku kepada satu pendapat saja justru berpotensi menimbulkan fanatisme keberagamaan atau keberislaman bagi kalangan santrinya. Jika telah demikian, maka tujuan dasar pesantren untuk mencetak para santri yang bijak dan cerdas justru tidak dapat tercapai, karena lebih mengutamakan kepentingan atau pendapat dirinya sendiri.
Dengan demikian, penting kiranya untuk membuka kotak pandora yang selama ini belum tersentuh, kecuali di beberapa pesantren modern yang memang mengenalkan kitab-kitab perbandingan mazhab, seperti Bidayat al-Mujtahid karangan Ibn Rusyd, karena tanpa adanya keanekaragaman pendapat yang diterima oleh para santri justru menghalangi terciptanya suatu tatanan masyarakat yang toleran dan saling menghormati satu sama lain. Makalah ini mencoba untuk mengulas tentang permasalahan tersebut dan meletakkan pesantren sebagai dasar kemajuan masyarakat Indonesia pada masa yang datang, sebagaimana telah diperankannya selama bertahun-tahun yang lalu.

\section{B. KITAB KUNING DAN KEHIDUPAN PESANTREN}

Pesantren memiliki karakteristik dan situasi kultural yang dapat dikatakan berbeda dari kehidupan sehari-hari bangsa Indonesia, walaupun keberadaannya dalam pembangunan sistem pendidikan Islam tidak bisa dikatakan baru. ${ }^{1}$ Rutinitas dan aktifitas eksklusif yang ada di pesantren menjadikan sistem pendidikan Islam tertua di Indonesia menjadi terpisah dari kehidupan di luarnya, terutama dalam pembangunan nilai-nilai keislaman dan tradisi keagamaan. Dalam suatu istilah yang sering digunakan,

\footnotetext{
1 Menurut catatan van Bruinessen, pesantren dengan sistem yang lengkap dan sempurna - di Indonesia baru muncul pasca ahkir abad kedelapan belas. Pada abad keenam belas pesantren masih berwujud sebagai pusat Islam kedua setelah masjid. Hal ini dapat diketahui dari survey Pemerintah Hindia Belanda pada 1819 yang menunjukkan bahwa pada masa ini belum ada pesantren yang betul-betul pesantren di seluruh pulau Jawa, karena pendidikan Islam masih berpusat di masjid atau rumah kyai. Lihat, Martin van Bruissen, "Pesantren dan Kitab Kuning", dalam Jurnal Ulumul Qur'an, vol. III, No. 4 tahun 1992, 77
} 
sebagaimana Abdurraham Wahid menyitir, Pesantren merupakan subkultur bila ditinjau dari luar, walaupun istilah ini digunakan banyak terdorong oleh ketiadaan istilah lain yang lebih tepat daripada sebagai hasil pengolahan data empiris yang dapat dipertanggungjawabkan secara ilmiah. ${ }^{2}$ Sebelum terlampau jauh masuk ke komponen-komponen keberadaan sebuah pesantren, sebagaimana disinggung di atas, penting untuk terlebih dahulu meninjau akar istilah dari pesantren itu sendiri.

Menurut Zamakhsyari Dhofier, istilah pesantren berasal dari kata santri, yang diimbuhkan awalan pe- dan akhiran -an yang berarti "tempat tinggal para santri". Kata santri sendiri berasal dari bahasa Tamil yang berarti guru mengaji. Dengan merujuk Berg, Zamakhsyari Dhofier menyatakan, bahwa kata santri berasal dari istilah shastri yang dalam bahasa India berarti orang yang tahu buku-buku suci Agama Hindu atau seorang sarjana kitab suci agama Hindu. ${ }^{3}$

Pendapat Berg ini nampaknya seiring dengan pendapat Steenbrink yang menyebutkan bahwa jika dilihat dari segi bentuk dan sistemnya, pesantren berasal dari India, yang dahulu kala digunakan oleh agama Hindu sebelum masuknya agama Islam ke Indonesia. Hal ini juga didukung oleh istilah lain yang sangat sering digunakan di lingkungan pesantren, yaitu "mengaji" yang menurutnya berasal dari bahasa India. Tidak hanya itu, adanya tradisi memberikan tanah untuk lembaga pendidikan sebagai kebiasaan yang terjadi di sistem pendidikan Islam ini juga dikenal pada ajaran Hindu. Kesamaan juga terjadi

\footnotetext{
2 Abdurrahman Wahid, Islam Kosmopolitas: Nilainilai Indonesia dan Transformasi Kebudayaan, (Jakarta: Wahid Institute, 2007), h 89

3 Zamakhsyari Dhofier, Tradisi Pesantren: Studi Tentang Pandangan Hidup Kyai, (Jakarta: LP3ES, 1982), 18.
}

dalam sistem pengajaran. Dengan menyadur pendapat Soegarda Poerbakawartja, Steenbrink menyatakan bahwa seluruh unsur pendidikan di pesantren adalah bersifat agama, guru-gurunya tidak diberikan gaji, serta para murid meminta santunan kehidupan ke luar pesantren, yang juga menjadi ciri khas pendidikan yang ada di agama Hindu. ${ }^{4}$

Di sisi yang lain, di Indonesia juga dikenal istilah Surau yang cukup dikenal di tanah Minang. Dilihat dari aspek tradisi dan sistem nilai yang ada di dalamnya, menurut Azyumardi Azra, surau juga memiliki kesamaan dengan tradisi dan sistem nilai pesantren yang banyak terdapat di pulau Jawa. Secara lebih spesifik, semua ini diaktualisasikan dengan penganutan kepada aliran teologis Asy`ari, fikih dari aliran Syafi i, dan tasawuf dari imam al-Ghazali. ${ }^{5}$

Pesantren adalah pusaka bangsa Indonesia. Sudah dikenal sejak ratusan tahun yang lalu, pesantren merupakan lembaga pendidikan yang sangat efektif dan berpengaruh besar bagi proses penyebaran Islam di Indonesia umumnya, di Jawa khususnya. Para "Wali Sanga" yang menyebarkan Islam di Pulau Jawa adalah perintis terkemuka sistem pendidikan pesantren. Pesantren Sunan Giri (Syeikh 'Ainul Yaqîn) adalah salah satu yang sangat terkemuka.

Dilihat dari aspek sistem yang digunakan, dalam Ensiklopedia Nurcholis Madjid disebutkan, bahwa pesantren merupakan kelanjutan dan pengembangan

\footnotetext{
${ }^{4}$ Karel Steenbrink, Pesantren, Madrasah, Sekolah: Pendidikan Islam dalam Kurun Moderen, (Jakarta: LP3ES, 1994), 21.

5 Azyumardi Azra, Dari Surau Ke Sekolah Dan Pesantren: Peluang Dan Tantangan Dalam Era Globalisasi Dan Otonomi Daerah, Makalah Semiloka "Pesantren Bersejarah Di Sumatera Barat" Bukittinggi, 17-19 Januari, 2003.
} 
lembaga serupa di dunia Islam. Cikal bakal pesantren dapat dirujuk kepada sistem pengajaran zâwiyah atau lengkapnya zâwiyat al-masjid (pojok masjid) yaitu ruang-ruang khusus yang disediakan untuk ruang belajar sekaligus penginapan para penuntut ilmu. Lama kelamaan dibuat bangunan tersendiri dan terpisah secara fisik dari bangunan utama masjid dan disebut ribâth, yang berarti bangunan terkait (annexed) dengan masjid. Di situlah kegiatan belajar-mengajar diselenggarakan dan di situ pula para murid menginap.

Disebutkan pula, nama lain untuk pesantren ialah "pondok" yang diindonesiakan dari perkataan Arab "funduq". Perkataan Arab ini sendiri berasal dari perkataan Yunani pandukheyon (pandocegon) atau pandokeyon (pandokegon) yang berarti penginapan dan dalam bahasa Arab modern "funduq" berarti hotel.

Dari pelbagai pendapat dan pandangan di atas, kiranya dapat diambil benang merah dari mana asal muasal kata pesantren tersebut. Walaupun teridentifikasi telah ada sejak masa-masa awal kemunculan Islam, yaitu ditandai dengan adanya "pojok-pojok masjid" sebagai tempat belajar dan semakin berkembang menjadi wadah pembelajaran Islam, kata pesantren yang digunakan untuk konteks keindonesiaan sendiri telah berakulturasi dengan kebudayaan lokal. Menariknya, kata pesantren yang dipandang berasal dari luar bahasa Arab atau istilah Islam dilekatkan dengan istilah bahasa Arab "funduq" yang menjadi pondok pesantren.

Sebagaimana di atas, pesantren dapat dikatakan telah lama tumbuh berkembang di Indonesia sebagai wadah pendidikan Islam, bahkan telah mewujud sebagai subkultur tersendiri dari lingkungan masyarakat di luarnya atau sistem pembelajaran di Indonesia secara umum. Terkait dengan subkultur ini, Gus Dur, sapaan akrab Abdurrahman Wahid, mengidentifikasi beberapa elemen penting yang mengkategorikan pesantren sangat berkarakter dan khas.

Secara sosiologis, menurut Gus Dur, sebuah subkultur minimal harus memiliki keunikannya sendiri dalam aspek-aspek tertentu, di antaranya adalah cara hidup yang dianut, pandangan hidup dan tata nilai yang diikuti, serta hirarki kekuasaan internal tersendiri yang ditaati sepenuhnya. ${ }^{6}$ Meskipun berangkat dari pengamatan dan belum sampai pada taraf penelitian mendalam terkait konsep tersebut, menarik kiranya untuk menilai konsep tersebut dengan menguraikan elemen-elemen yang ada di pesantren, seraya membandingkan apakah unsur-unsur sebuah subkultur telah terpenuhi di lembaga pendidikan Islam tersebut.

Ada beberapa elemen yang dikemukakan oleh para peneliti terkait pesantren di Indonesia dan elemen-elemen ini menentukan apakah suatu lembaga pendidikan Islam laik untuk dikatakan pesantren atau tidak. Adalah Zamakhsyari Dhofier yang cukup banyak dirujuk untuk permasalahan ini, yang menyatakan bahwa pesantren biasanya diidentifikasi dengan elemen-elemen yang harus dipenuhinya, di antaranya adalah adanya pondok (tempat para murid menginap), masjid (yang menjadi pusat ibadah dan belajar), santri (mereka yang tinggal dan menimba ilmu), pengajaran kitab Islam klasik, dan adanya kyai (yang mengasuh, sekaligus menjadi panutan bagi siapapun yang ada di pesantren). ${ }^{7}$

Dari beberapa karakter atau ciri dari sebuah pesantren, pengajaran kitab-kitab

\footnotetext{
${ }^{6}$ Abdurrahman Wahid, Islam Kosmopolitas, 94.

${ }^{7}$ Zamakhsyari Dhofier, Tradisi Pesantren, 45
} 
klasik yang dikenal dengan kitab kuning adalah yang cukup unik untuk diperdalam, selain dari kedudukan kyai/nyai di pesantren yang secara sosiologis dan antropologis menarik perhatian sejumlah ahli. Dari kitab kuning ini dikenal istilah ngaji, yaitu sebuah proses pembelajaran seorang santri kepada kyai atau santri senior yang telah diberikan amanat oleh kyai. Ngaji atau sering pula dikenal dengan pengajian, menurut Ronald Lukens, merupakan tindakan dalam membaca teks-teks arab, terutama Alquran. Istilah ini tidak hanya digunakan oleh kalangan pesantren saja, tetapi juga di luarnya, terutama untuk menggambarkan tindakan "membaca Alquran".

Di pesantren - salafi terutama, pengajaran kitab kuning telah mendapatkan bentuknya yang tertata. Seorang santri memilih sebuah kitab yang sesuai dengan tingkatannya dan membacanya di bawah bimbingan kyai. Ada beberapa jenis proses pembelajaran ini, yaitu yang dikenal dengan sorogan dan bandongan, di mana seorang kyai yang mengajarkan kitab kuning ini bersifat aktif dan santri bersifat pasif mendengarkan. Secara teknis model sorogan bersifat individu, yaitu santri menghadap guru seorang demi seorang dengan membawa kitab yang akan dipelajari. Sementara model bandongan, lebih bersifat pengajaran klasikal, yaitu santri mengikuti pelajaran dengan dukuk di sekeliling kyai yang menerangkan pelajaran-pelajaran melalui metode kuliah dan terjadwal. ${ }^{8}$

\section{PESANTREN DAN TANTANGAN MODERNISASI}

Sebagai sebuah pendidikan Islam yang berangkat dari tradisi masyarakat Muslim dan sangat sarat dengan budaya tradisional,

\footnotetext{
${ }^{8}$ Ronald Lukens Bull, A Peaceful Jihad: Negotiating Identity and Modernity in Muslim Java, (MacMillan: Palgrave, 2005), 54-55
}

pesantren menghadapi tantangan yang tidak kecil tatkala harus masuk ke dunia modern seperti sekarang ini. Tantagan-tantangan tersebut mewujud dalam pelbagai bentuk, baik dari segi struktur dan kelembagaan maupun nilai-nilai normatif yang dikembangkan di pesantren, termasuk pula ilmu pengetahuan yang menjadi obyek pembelajaran kalangan pesantren seharihari. Dengan klasifikasi antara pesantren salaf dan modern, dapat diketahui sekilas bahwa pesantren salaf merupakan institusi pendidikan Islam yang paling besar menghadapi tantangan tersebut, mengingat pesantren modern telah banyak melakukan pembaruan sistem dan kurikulum sejak awal pendirian atau kemunculannya. ${ }^{9}$ Catatan Ahmad El Chumaedy menggambarkan kondisi tersebut. Menurutnya:

Indegenousitas pesantren kontras berbeda dengan praktek pendidikan pada intitusi pendidikan lainnya, sehingga dinamika sekaligus problematika yang muncul kemudian, juga menampilkan watak yang khas dan eksotik. Di era globalisasi sekarang ini, Alfin Toffler membayangkan akan terciptanya 'masyarakat informasi' (the informasional society) yang sulit untuk dihindari oleh negara manapun di permukaan bumi ini, termasuk Indonesia. Sehingga, fenomena globalisasi yang begitu cepat mengalami akselerasi dalam pelbagai aspek, sebagai konsekuensi logis dari penerapan high-tech (tekhnologi tinggi), menyebabkan bangsa Indonesia tergiring pada pola interaksi yang amat cepat dan massif dengan negara-negara lain di dunia. Dalam fase masyarakat informasi inilah,

\footnotetext{
9 Walaupun klasifikasi ini juga sebetulnya tidak mutlak, karena ada beberapa pesantren modern yang tidak menerapkan pendidikan/kurikulum formal Kementerian Agama dan Kementerian Pendidikan Nasional, sementara di sisi yang lain terdapat pesantren salaf yang justru menggunakan sistem pendidikan modern ini.
} 
pesantren semakin menghadapi tantangan yang tidak ringan dan lebih kompleks ketimbang periode waktu sebelumnya. ${ }^{10}$

Kurikulum pesantren salaf cenderung berkiblat ke model pendidikan ribath di Hadramaut, Yaman. Hal ini dapat dimaklumi, karena para dai atau kyai yang awalnya menyebarkan Islam di Jawa memang berasal dari sana. Yang cukup mencolok, bila dibandingkan dengan pesantren modern, adalah penekanannya dalam bidang fikih, tasawuf dan ilmu alat.

Karakteristik lain yang juga terlihat dari pendidikan pesantren adalah dalam struktur pendidikan yang diberikan. Bila dalam sekolah umum yang dianut oleh hampir seluruh sekolah-sekolah modern adalah adanya jenjang pendidikan pasti, mulai dari pendidikan dasar, menengah pertama dan atas, bahkan sampai ke perguruan tinggi. Setiap jenjang dihabiskan oleh para siswa dalam rentang waktu tertentu. Di pesantren, dijumpai jenjang pesantren yang berulang-ulang dari satu tingkat ke tingkat lain tanpa terlihat kesudahannya. Bahkan, pembahasan yang diajarkan pun seringkali berulang-ulang selama waktu bertahun-tahun, walaupun buku yang digunakan adalah berlainan. ${ }^{11}$

Biasanya dimulai dengan kitab yang paling kecil/rendah (mukhtashar), sebuah buku yang berisikan tentang teks ringkas dan sederhana. Walaupun sederhana dan biasanya tipis, pengajian kitab tersebut biasanya menghabiskan waktu bertahuntahun dan bila telah dihabiskan, barulah seorang santri dapat berpindah ke kitab tingkat "sedang" (mutawasshitah). Dengan

10 Ahmad El Chumaedy, "Membongkar Tradisionalisme Pendidikan Pesantren: Sebuah Pilihan Sejarah", 6 Oktober 2002, diakses dari http://re-searchengines.com/achumaedy.html

\footnotetext{
${ }^{11}$ Abdurrahman Wahid, Islam Kosmopolitas, 91.
}

sistem seperti ini dan pelbagai pilihan subyek kitab yang ditawarkan, setiap santri dapat memilih secara acak kitab-kitab mana saja yang hendak dipelajari. Jika ternyata yang dipilih adalah seluruh subyek judul, dapat dibayangkan berapa tahun atau bahkan puluhan tahun seorang santri akan menghabiskan masa studinya untuk menjadi ahli dan menyelesaikan semua tingkatan pelajaran.

Walaupun demikian, pesantren yang masih menerapkan sistem pendidikan seperti ini tidak mengenal adanya ujian atau hasil pembelajaran (raport atau ijazah) seperti di sekolah-sekolah umum, sehingga setiap santri tidak wajib dan terikat untuk menyelesaikan semua tingkatan. Dari sistem tersebut, yang menjadi ukuran prestasi atau keberhasilan dari seorang santri adalah berapa lama ia bisa mencari ilmu (ngelmu) kepada seorang kyai dan sejauh mana ketundukannya kepada kyai tersebut. ${ }^{12}$ Gambaran pesantren tersebut memberikan suatu kesimpulan sementara, bahwa setiap santri yang hendak menimba ilmu kepada seorang kyai harus memiliki keitiqamahan (konsistensi) untuk mencari ilmu dan sabar dalam menghadapi setiap halangan dan rintangan kehidupan pesantren dalam waktu yang lama. Hal ini tentu tidak akan ditemui oleh seorang siswa yang mengikuti sistem pendidikan umum.

Tantangan lain yang juga dihadapi oleh pesantren adalah tatacara atau metode pendidikan yang diberikan. Pelajaran diberikan oleh sang kyai berbentuk kuliah umum terbuka, di mana seorang kyai membaca, menerjemahkan dan menjelaskan persoalan-persoalan yang disebutkan di dalam teks yang sedang dipelajari. Kemudian sang santri membaca ulang teks tersebut, baik di hadapan kyai ataupun setelah mereka kembali ke bilik/pondok

\footnotetext{
${ }^{12}$ Abdurrahman Wahid, Islam Kosmopolitas, 92.
} 
masing-masing, ataupun juga dalam pengajian ulang antara sesama teman setingkat pengajian. Di samping itu, kyai juga akan memantau dan memperhatikan apakah pelajaran-pelajaran tersebut teraplikasi dalam kehidupan santri seharihari atau tidak.

Sistem atau metode pengajaran yang berbeda dari pendidikan umum inilah yang kemudian memberikan identitas unik bagi kalangan pesantren. Metode tersebut tidak hanya terhenti pada tataran pengetahuan (stockknowledge) seorang santri, tetapi juga menghasilkan pandangan hidup dan aspirasi yang khas pula. Tidak jarang bahkan sementara ahli mengenalkan sistem tersebut dengan nama "cara kehidupan santri" seperti yang disitir oleh Clifford Geertz dalam bukunya The Religion of Java. ${ }^{13}$

Perkembangan yang telah berlangsung lama ini, mengingat semakin maju dan berkembangnya kondisi masyarakat dan semakin kompleks pula cita dan harapan mereka terhadap lembaga pendidikan, sistem pembelajaran seperti ini terkadang menuai pertanyaan di masyarakat sendiri. Sebut saja misalnya mengenai kurikulum, sarana-prasarana, tenaga kependidikan (pegawai administrasi), guru, pengelolaan, sistem evaluasi dan aspek-aspek lainnya dalam penyelenggaraan pendidikan di pesantren. Pada tataran ini, pesantren seringkali berhadap-hadapan dengan dilema antara tradisi dan modernitas. Menurut pandangan Chumaedy, tatkala pesantren tidak mau beranjak ke modernitas dan tetap mempertahankan otentisitas tradisi pengajarannya yang khas tradisional, tanpa adanya pembaharuan metodologis, maka selama itu pula pesantren harus siap ditinggalkan oleh masyarakat. ${ }^{14} \mathrm{Hal}$ inilah

\footnotetext{
${ }^{13}$ Abdurrahman Wahid, Islam Kosmopolitas, 93.

14 Ahmad El Chumaedy, "Membongkar Tradisionalisme Pendidikan Pesantren”.
}

yang menjadi salah satu tantangan besar dunia pesantren, bila tidak secara serius disikapi dengan pembaruan dan perubahan sistem yang ada, tetapi juga tanpa menghilangkan karakter pesantren yang telah terbentuk lama.

Karakter lain yang juga dimiliki pesantren adalah posisi seorang kyai yang terkadang sangat ahli di bidang-bidang tertentu, sehingga seseorang yang hendak belajar tentang ilmu tersebut harus datang ke kyai-kyai yang berlainan. Sebagai contoh, misalnya, adalah kyai Hasyim Asy'ari di Tebu Ireng yang dinilai sangat ahli di bidang hadis, sementara Pesantren Jampes di Kediri sangat dikenal dengan pengajaran tasawufnya. Ada pun pesantren yang lebih mengklasifikasikan ke pengajaran Alquran. Dengan demikian, sebagaimana catatan Ronald Lukens, seorang santri yang hendak mendalami ilmu hadis, ia dapat pergi ke Pesantren Tebu Ireng dan mengaji kepada Hasyim Asy'ari, sementara yang hendak mendalami ilmu tasawuf ia dapat mengunjungi Pesantren Jampes di Kediri. ${ }^{15}$ Hal ini pula yang menyebabkan kuatnya tradisi perpindahan santri dalam menuntut ilmu secara horizontal, dari satu pesantren ke pesantren lainnya untuk lebih mendalami bidang ilmu agama Islam.

Sistem pembelajaran tersebut tentu berbeda dengan sistem pembelajaran yang ada di sekolah-sekolah umum dan lebih mengenal sistem perpindahan vertikal dari tingkat yang lebih rendah sampai tingkat yang lebih tinggi. Dengan sistem pendidikan berjenjang dewasa ini, sistem pembelajaran pesantren yang mengandaikan perpindahan horizontal tersebut tentu sangat menjadi kendala bagi seseorang yang hidup di zaman modern sekarang ini. Namun bila dilihat dari produk yang dihasilkan, sistem pembelajaran seperti ini tidak dapat

\footnotetext{
${ }^{15}$ Ronald Lukens Bull, A Peaceful Jihad, 53.
} 
diragukan lagi keberhasilannya dalam membentuk seorang santri menjadi ahli dan mapan dalam ilmu keislaman. Zamakhsyari Dhofier memberikan gambaran tentang produk dari sistem pembelarajan tersebut dalam sosok seorang kyai Wahab Hasbullah, kyai Pesantren Tambah Beras, Jombang, menggantikan ayahnya dan salah satu pendiri Nahdhatul Ulama, organisasi masyarakat Islam terbesar di Indonesia.

Menurut Zamakhsyari Dhofier, pada masa pengembaraan Wahab Hasbullah menuntut ilmu, ia pergi ke pelbagai tempat dan belajar ke banyak kyai di Jawa, seperti ke kyai Kholil Bangkalan dan kyai Hasyim Asy'ari. ${ }^{16}$ Sistem pembelajaran ini juga menghasilkan banyak kyai besar seperti Wahab Hasbullah.

Salah satu karakter yang dimiliki pesantren dalam pengajaran kitab kuning, sebagaimana disebutkan di atas, adalah dalam pembelajaran kitab kuning. Hampir di seluruh pesantren salaf, pembelajaran kitab kuning diberlakukan untuk semua bidang keilmuan, seperti fikih, ushuluddin (teologi), hadis, bahasa Arab, tasawuf, akhlak, dan doa-doa. Dari pelbagai kitab yang diajarkan tersebut, menurut banyak penelitian menyebutkan, kebanyakan kitab-kitabnya adalah karya para ulama Syafi'iyah. Dalam konteks fikih, misalnya, yang diajarkan mulai dari kitab fikih tingkat dasar, seperti Safinat al-Naja, Taqrib, Kifayat al-Ahyar; tingkat menengah, seperti Fath al-Qarib, Fath al-Wahab, Fath al-Mu'in, I'anat alThalibin, Hasyiyah al-Bajuri, Muhazzab; hingga tingkat tinggi, seperti Nihayat alMuhtaj, Hasyiyah al-Qalyubi wa Umairah, Al-Muharrar, Majmu Syarh Muhazzab. ${ }^{17}$

\footnotetext{
16 Zamakhsyari Dhofier, Tradisi Pesantren, 17.

17 "Reinventing Kitab Kuning dalam Tradisi Pesantren", Sunday, 10 Agustus 2008, Artikel dimuat dalam Jurnal al-Mighrab, Pekapontren Depag RI, Agustus 2008, diakses dari http://abdullah-
}

Sistem pembelajaran yang lentur dan tidak terstruktur dengan baik ini memunculkan banyak kritik dari sementara kalangan. Tholhah Hasan yang mengkritik standarisasi keilmuan di pesantren, menyebutkan, bahwa standarisasi di pesantren adalah persoalan yang sangat sulit untuk diwujudkan. Hal ini terjadi karena terdapat pesantren yang memang dibentuk setelah melalui pertimbangan yang matang, berdasarkan satu visibilitie study, tetapi ada juga pesantren yang dibesarkan berdasarkan hobi atau niat dari seorang kyai saja. Untuk yang kedua, karena kurangnya manajerial pesantren, terkadang akhirnya memunculkan masalah pada visi keilmuan pesantren. Implikasinya, keilmuan di banyak pesantren sangat tidak berimbang dan cenderung fikihsentris. Materi pembelajaran fikih ini pun terkadang tidak seiring dengan materi pembelajaran ushul fikihnya, karena terkadang fikihnya masih di tingkat rendah, tetapi ushul fikihnya sudah di tingkat paling tinggi, atau sebaliknya. ${ }^{18}$

Seiring dengan berkembangnya waktu, terdapat pembaruan-pembaruan yang dilakukan oleh dunia pesantren dengan semakin pesatnya perkembangan modernitas. Hal ini setidaknya dapat dilihat dari beragam bentuk dan sifat dari pesantren sekarang ini. Dalam banyak literatur tentang pesantren dinyatakan sejumlah tipe atau klasifikasi pesantren, mulai dari pesantren salaf, khalaf atau modern, sampai pesantren yang menggabungkan keduanya.

Pesantren salaf, sebagaimana diterapkan di pesantren Al-Anwar, Sarang, Rembang (Jawa Tengah), Pacul GowangJombang (Jawa Timur) atau Lirboyo-Ploso Kediri (Jawa Timur), merupakan sistem

\footnotetext{
ubaid.blogspot.com/2008/08/pesantren-dan-kitabkuning-adalah-dua.html

18 Jufri Dolong, "Mengembangkan (Potensi) Pesantren", Kamis, 13 November 2008
} 
pembelajaran yang meneruskan tradisionalisme pesantren sejak pertama kali muncul di Indonesia. Ada beberapa karakter pesantren salaf ini, di antaranya adalah manajemen dan administrasi pesantren sangat sederhana dengan sistem pengelolaan pesantren berpusat pada aturan kiai yang diterjemahkan oleh pengurus pesantren; sangat terikat pada figur kiai; pola dan sistem pendidikan bersifat konvensional atau berpijak pada tradisi lama dengan proses belajar-mengajar bersifat searah (kiai berceramah dan santri mendengarkan), metode pengajaran dikenal dengan sebutan sorogan dan bandongan (wetonan), dan tidak mengenal jenjang kelas; bangunan dan asrama santri tidak tertata rapi dan umumnya menyatu dengan alam. Menurut beberapa catanan, sebagian besar pesantren di Indonesia masih menggunakan sistem salaf, yang bila ditotal keseluhannya mencapai sekitar 8.905 pesantren.

Tipe kedua adalah pesantren khalaf atau modern, seperti yang diterapkan di pesantren Darussalam, Gontor (Jawa Timur), Al-Zaitun, Solo (Jawa Tengah), Darunnajah dan Darurrahman (Jakarta), Pesantren Thawalib, Padang Panjang (Sumatera Barat), dan lain-lain. Pesantren modern ini ditandai beberapa ciri dan karakteristik yang membedakannya dengan pesantren salaf, di antaranya adalah memiliki manajemen dan administrasi dengan standar modern; tidak terikat atau tersentral pada figur kiai; memiliki pola dan sistem pendidikan modern dengan perpaduan kurikulum antara mata ajar berbasis ilmu agama dan mata ajar berbasis pengetahuan umum; sarana dan bentuk bangunan pesantren lebih mapan, teratur, permanen, dan biasanya berpagar.

Bentuk ketiga yang merupakan jawaban atas kedua pesantren di atas adalah pesantren terpadu, yang menyatukan antara sistem salaf dan khalaf sekaligus. Pesantren- pesantren terpadu ini dapat dilihat dari sistem pesantren Tebuireng, Jombang (Jawa Timur) dan Mathali'ul Falah, Kajen (Jawa Tengah). Pesantren terpadu ini memiliki ciri khas nilai-nilai tradisional yang masih kental, sebab kiai masih dijadikan figur sentral, selain juga mengadopsi nilai-nilai modernitas terbatas. Norma dan kode etik pesantren klasik masih menjadi standar pola relasi dan etiket keseharian santri dalam pesantren, namun pesantren terpadu ini telah mengadaptasi sistem pendidikan modern sebagai bentuk respon atau penyesuaian terhadap perkembangan lembaga-lembaga pendidikan non-pesantren. Di Indonesia, jumlah pesantren seperti ini cukup banyak yang mencapai sekitar 4.284 pesantren. ${ }^{19}$

Adanya anekaragam sistem pembelajaran pesantren tersebut, terutama dalam konteks modernisasi pesantren, dapat dikatakan bahwa pada dasarnya pesantren telah mampu menjawab permasalahanpermasalahan yang datang untuk dapat tetap eksis di tengah kehidupan masyarakat Indonesia.

Salah satu contoh dari upaya pembaruan atau modernisasi pesantren ini adalah yang dilakukan oleh pesantren Tebu Ireng dengan kedua kyai besarnya Muhammad Ilyas dan Wahid Hasyim. Tebu Ireng diidentifikasi oleh para ahli yang mengamati pesantren sebagai pesantren pelopor pembaruan tersebut. Sejak 1929 kedua Kyai ini telah memasukkan mata pelajaran umum di pesantren, selain dari sistem pendidikan dan pembelajaran wetonan yang menjadi ciri khas pesantren tradisional. Hal ini menjadi jawaban atas penolakan sementara pesantren terhadap

\footnotetext{
${ }^{19}$ Mulyadi J. Amalik, "Pesantren, Pendidikan Islam Khas Indonesia (2) “, 18 November 2008, makalah diakses dari www.kabarindonesia.com
} 
sistem belajar (wetonan) tersebut, sehingga terjadi elaborasi sistem pendidikan. ${ }^{20}$

Di samping itu, pembaruan pesantren juga mengarah kepada pengembangan fungsi pesantren, yang tidak hanya mengutamakan fungsi pendidikan, tetapi juga merambah kepada fungsi pengembangan masyarakat. Dari fungsi tersebut, sebuah pesantren diharapkan tidak hanya mampu menciptakan para kyai atau orang-orang yang mampu dalam ajaran agama Islam, namun juga mempunyai wawasan yang luas, cakrawala pemikiran dan mampu pula memenuhi tuntutan zamannya dalam rangka pemecahan permasalahan masyarakat. $^{21}$

Secara lebih masif dan mendapatkan momentumya, modernisasi lembaga pendidikan Islam ini tatkala Indonesia memasuki zaman kemerdekaan. Hal ini didasari oleh realitas bahwa sebelum kemerdekaan, selama puluhan tahun dijajah Belanda dan umat Islam terdiskriminasi. Era kemerdekaan dipandang sebagai peluang untuk lebih mengembangkan lagi sistem pendidikan Islam, karena pendidikan Islam telah dipandang setara. Pada masa awal kemerdekaan, pendidikan Islam mulai dianggap sebagai pendidikan formal oleh pemerintah dan perubahan yang signifikan adalah masuknya pengaruh pemerintah pada pendidikan pesantren, baik dari Departemen Pendidikan dan Kebudayaan atau dari Departemen Agama. Pada masa ini pula banyak pesantren yang awalnya swasta berubah status menjadi pendidikan negeri,

${ }^{20}$ M. Dawam Rahardjo, Kehidupan Pemuda Santri: Penglihatan dari Jendela Pesantren Pabelan, dalam M. Dawam Rahardjo (ed.), Pesantren dan Pembangunan, (Jakarta: LP3ES, 1995), cet. V, 106.

21 Mochtar Buchari, Pendidikan Islam di Indonesia: Problem Masa Kini dan Perspektif Masa Depan, dalam Muntaha Azhari dan Abdul Mu'in (ed.), Islam Indonesia Menatap Masa Depan, (Jakarta: P3M, 1989), 186. sehingga dalam pesantren timbul sekolahsekolah negeri seperti SD, SMP, SMA, Madrasah Ibtidaiyyah, Madrasah Tsanawiyah, dan sebagainya. ${ }^{22}$

Perubahan atau pembaruan juga terjadi di wilayah substantif untuk beberapa pesantren. Tradisi pembacaan kitab kuning yang awalnya menggunakan sistem pembelajaran tradisional lambat laun mengalami perubahan. Sebagaimana diketahui, dalam tradisi klasik pengajaran kitab kuning lebih mengutamakan sistem hafalan, setelah sang kyai mengajarkan dan menerangkan maksud-maksudnya. Hal ini dipandang tidak cukup memadai oleh sementara kyai pesantren, sehingga mengubah sistem pembelajaran yan ada dengan lebih mengutamakan ilmu alat, yaitu bahasa. Adalah Imam Zarkasyi, tokoh yang mendirikan pesantren modern Darussalam Gontor, telah mengubah format sistem pembelajaran kitab tersebut, yang lebih diorientasikan pada penguasaan bahasa Arab secara teknis dan bukan hafalan. ${ }^{23}$ Hal ini menurutnya lebih dibutuhkan oleh kalangan santri untuk lebih menguasai bidang-bidang keilmuan Islam dan mengembangkan intelektualitas mereka.

Imam Zarkasyi mengembangkan sistem belajar bahasa Arab, dengan cara memperbanyak latihan, baik lisan maupun tulisan, serta menggunakan alat peraga yang tidak didapati di pesantren tradisional. Dari sini kemudian ia mengkritik sistem hafalan di pesantren, karena menurutnya, kemampuan seorang santri untuk

\footnotetext{
22 Syafi'i Ahmadi, Pendidikan Islam pada Masa Orde Lama, dalam Abuddin Nata, Kapita Selekta Pendidikan Islam (Bandung: Angkasa, 2003), h. 38; lihat pula, M. Dawam Rahardjo, Kehidupan Pemuda Santri: Penglihatan dari Jendela Pesantren Pabelan, 106.

23 Habib Chirzin, Agama dan Ilmu Pengetahuan, dalam Dawam Rahardjo (ed.), Pesantren dan Pembangunan, 91.
} 
memfungsikan satu kata dalam seribu susunan kalimat adalah lebih baik dan penting dibandingkan menguasai seribu kata masing-masing dalam satu kalimat saja. ${ }^{24}$ Dengan sistem pembelarajannya ini, bila hendak melihat hasil atau produk pendidikan yang diajarkan oleh pesantren Gontor, tidak sedikit para intelektual Muslim Indonesia dewasa ini berasal dari pesantren tersebut.

Dari gambaran singkat pesantren tersebut di atas, cukuplah dimengerti bahwa perubahan pesantren, sedikit banyaknya, adalah perlu dilakukan, meskipun tetap menjaga orisinalitasnya sebagai lembaga pendidikan Islam yang tumbuh puluhan bahkan ratusan tahun. Dari sini pula, masing-masing pesantren, baik klasik, modern, atau perpaduan di antara keduanya, telah memiliki karakter dan kelebihan masing-masing dalam mengembangkan ilmu pengetahuan di Indonesia. Dengan karakter masing-masingnya, pendidikan di pesantrenpesantren ini telah mampu menyumbangkan peradaban keilmuan Islam Indonesia seperti sekarang ini, yang bisa jadi sangat sulit ditemukan di dalam masyarakat-masyarakat Islam di seluruh dunia yang lebih bersifat monoton dan homogen. Dalam itu pula, perlu untuk selalu mengembangkan pesantren sebagai lebaga pendidikan Islam untuk mendapatkan hasil yang lebih maksimal bagi pembangunan bangsa Indonesia ke depan.

Lebih awal lagi, pembaruan sistem pesantren dilakukan oleh para Ulama lama sebelum pesantren terdefinisikan dengan baik, yaitu saat awal-awal pesantren tumbuh. Menurut Strenbrink, awalnya pendidikan tersebut hanya sebatas pendidikan Alquran, kemudian berlanjut dengan adanya kurikulum pembacaan kitabkitab Islam klasik. Proses pembelajaran informal ini mulai ditinjau ulang oleh para

\footnotetext{
${ }^{24}$ Habib Chirzin, Agama dan Ilmu Pengetahuan, 91.
}

kyai atau pengajar ketika memasuki fase kolonialisme pada akhir abad ke-18, karena spesifikasi dan pendikotomian ilmu pengetahuan mulai dirasakan. Dalam penelitiannya Steenbrink mencatat bahwa pendidikan kolonial sangat berbeda dengan pendidikan agama yang lebih mengorientasikan pada kemampuan dan keterampilan yang berguna bagi penghayatan agama. Sementara pendidikan kolonial lebih mengkhususkan pada ilmu pengetahuan dan keterampilan yang berguna bagi kehidupan duniawi. ${ }^{25}$ Gambaran ini menunjukkan bagaimana pesantren selalu berevolusi dari waktu ke waktu dan perubahan merupakan suatu bagian penting dari pesantren yang tidak dapat dipisahkan.

\section{AKTUALISASIn FIKIH PESANTREN DAN TRANSFORMASI MASYARAKAT INDONESIA MODERN}

Sebagaimana yang telah dijelaskan dalam sejumlah penggalan paragraf di atas, pesantren tidak dapat dipisahkan dari tradisi kitab kuning dan fikih. Hal ini tidak bisa dilepaskan dari tradisi pesantren yang telah berumur puluhan bahkan ratusan tahun yang lalu dan telah menjadi subkultur tersendiri dalam kehidupan umat Islam Indonesia.

Sebagai sebuah subkultur masyarakat Indonesia, pesantren tidak hanya mengandung unsur keaslian (indigenous) Indonesia, tetapi juga mengandung unsur keislaman. Pesantren yang awalnya sebagai lembaga pendidikan, penyiaran agama Islam, reproduksi ulama dan pemelihara Islam tradisional, seiring dengan adanya perubahan dalam masyarakat identitas

\footnotetext{
${ }^{25}$ Karel Steenbrink, Pesantren, Madrasah, Sekolah, 16.
} 
pesantren juga mengalami perubahan. ${ }^{26}$ Perubahan-perubahan ini yang mengarahkan pesantren menjadi sebuah institusi yang berperan di masyarakat dan melampaui fungsinya hanya sekedar lembaga pendidikan.

Selama kurun waktu yang telah berlalu, Azyumardi Azra mencatat, bahwa setidaknya pesantren memiliki tiga ciri yang menyandinginya, yaitu pertama, sebagai pusat pengetahuan keagamaan; kedua, mempertahankan nilai-nilai tradisi Islam; dan, ketiga, sebagai pusat pencetak para ulama atau kyai. ${ }^{27}$ Fungsi-fungsi tersebut yang kemudian tidak boleh dihilangkan dari pesantren, selain juga menambahkan peranan-peranan lain yang mungkin dihandle-nya seiring dengan perkembangan dan kemajuan zaman dewasa ini.

Terkait dengan hal ini, salah satu tradisi pesantren yang harus pula menjadi perhatian, terutama dalam konteks pengajaran kitab kuning, adalah kuatnya khazanah pemikiran hukum Islam Syafii, yang dalam tahap tertentu masih dibutuhkan, tetapi di sisi yang lain, perlu pula untuk dikembangkan lebih lanjut.

Berangkat dari suatu pernyataan yang sering dikemukakan oleh Harun Nasution, bahwa pandangan plural terhadap aliranaliran fikih akan mengarahkan seseorang dapat memahami keanekaragaman di lingkungan sekitarnya, tidak hanya terhadap aliran dalam satu agama (Islam), tetapi juga pandangan-pandangan lain yang berbeda di

\footnotetext{
26 Dampak Perubahan Orientasi Pondok Pesantren Terhadap Masyarakat, Rabu, 24 September 2008, www.pondokpesantren.net

27 Azyumardi Azra dan Dina Afriyanti, Pesantren And Madrasa: Modernization Of Indonesian Muslim Society, makalah pada Workshop on Madrasa, Modernity and Islamic Education, Boston University, CURA, 6- 7 Mei Tahun 2005.
}

luar agamanya. $^{28}$ Dari sini pula, salah seorang ahli filsafat terkemuka, Nietsche, pernah mengemukakan pendapat yang serupa, yaitu semakin banyaknya informasi yang diterima oleh seseorang terkait suatu hal, maka semakin relatif dan moderat pula pandangannya. Menurut Nitsche, hal ini dapat meminimalisasi fanatisisme seseorang terhadap sebuah keyakinan atau ideologi, selain juga sebagai upaya prefentif terhadap puritanisme berkeyakinan/ideologis. ${ }^{29}$

Dari hal tersebut, menarik untuk melihat bagaimana tradisi pembelajaran kitab kuning di pesantren yang masih terfokuskan kepada satu mazhab saja, yaitu Syafi'iyah. Dalam batas tertentu, praktik pengajaran seperti ini adalah baik dan tidak mengandung implikasi negatif, bila sang guru memahamkan kepada para santri bahwa ada banyak pandangan lain yang berbeda di luar mazhab ini. Namun dalam kondisi sang guru atau kyai menutup rapatrapat adanya ikhtilaf pendapat yang sebetulnya telah ada secara de facto dalam sejarah Islam, maka hal ini justru akan memunculkan fanatisisme bermazhab atau bahkan eksklusifitas dalam beragama. Jika demikian adanya, tentu hukum Islam yang seharusnya lebih dapat dikembangkan justru terhenti pada pemahaman kaku dan taklid,

\footnotetext{
28 Pandangan ini disebutkan oleh Harun Nasution dalam bukunya Islam Ditinjau dari Berbagai Aspek yang ditulisnya sebagai buku ajar pokok mahasiswa IAIN. Dalam bukunya ini, Harun Nasution menerapkan apa yang ia yakini tersebut, yaitu dengan menghadirkan pelbagai macam pandangan dalam Islam, baik dari sisi aliran hukum Islam, teologis, tasawuf, dan sebagainya, sehingga setiap orang dapat memahami bagaimana Islam berdiri di atas keanekaragaman dan keragaman itu telah menjadi sunnah Allah di dalam sejarah umat Islam.

${ }^{29}$ Pendapat ini dikutip dari artikel A. Setyo Wibowo, "Pencerahan di Mata Kant dan Nietzsche: Menjadi Dewasa dan Rekonyal", dalam Jurnal Diskursus, Vol. 8, No. 1, April 2009, h. 27; lihat pula, A. Setyo Wibowo, Gaya Filasafat Nietzsche, (Yogyakarta: Galang Press, 2004), 174
} 
karena tidak adanya alternatif lain yang dapat ditawarkan oleh seseorang kecuali apa yang ada di dalam satu mazhab tertentu.

Adanya pandangan yang eklektis dan fleksibel terhadap mazhab fikih Islam merupakan sebuah keniscayaan dewasa ini, apalagi semakin maju dan berkembangnya kehidupan masyarakat. Sebagaimana diketahui, dalam perkembangan hukum Islam kontemporer, talfiq atau menggunakan beragam pandangan dari pelbagai mazhab fikih telah menjadi salah satu solusi bagi para ahli hukum Islam untuk menjawab modernitas hukum Islam hampir di seluruh Negara-negara Muslim, di samping dari metode lain, seperti siyasah syar'iyyah. Hal ini membuktikan bahwa pandangan yang hanya terpaku pada satu aliran fikih dan mengikuti aliran tersebut secara membabibuta justru tidak akan memberikan jawaban atas permasalahan kontemporer. Taklid buta ini justru akan membawa Islam kepada keterpurukan dan keterlakangan hukum Islam, karena tidak mampu menjawab problematika dan permasalahan baru di masyarakat yang setiap saat dapat saja muncul.

Mengembangkan orientasi pendidikan fikih di pesantren ini sangat perlu untuk dilakukan mengingat peranan yang telah dimiliki oleh pesantren selama ini. Pesantren adalah adalah lembaga pendidikan tradisional Islam untuk mempelajari, memahami, mendalami, menghayati, dan mengamalkan ajaran Islam dengan menekankan pentingnya modal keagamaan sebagai pedoman perilaku sehari-hari. Pengertian tradisional di sini menunjuk bahwa pesantren sebagai lembaga pendidikan agama (Islam) telah hidup sejak 300 - 500 tahun lalu dan telah menjadi bagian yang mengakar dalam kehidupan sebagian besar umat Islam Indonesia, dan telah mengalami perubahan dari masa ke masa. ${ }^{30}$ Dengan peranan yang begitu besar dan meluas tersebut, amat disayangkan bila potensi ini tidak dimanfaatkan lebih maksimal dalam membangun Indonesia yang lebih baik.

Perubahan ini tentu tidak dimaksudkan untuk mengubah tradisi pesantren, akan tetapi lebih mengembangkan lagi wacana fikih pesantren yang selama ini telah tumbuh dan agar dapat memberikan implikasi positif kepada masyarakat Indonesia ke depan. Merujuk sejumlah upaya pembaruan tersebut, yang cukup relevan untuk dilihat adalah bagaimana pesantren mulai mengenalkan pendekatan ijtihadi dalam hukum Islam untuk menjawab problematika permasalahan kontemporer yang belum tentu terjawab oleh tumpukan khazanah fikih klasik. ${ }^{31}$

Dalam hal ini, pengembangan studi pesantren yang dimaksud dalam artikel ini adalah bagaimana pesantren mulai mengenalkan aliran-aliran fikih selain dari Syafiiyah agar para santri mendapatkan gambaran utuh tentang hukum Islam itu sendiri. Lebih dari itu, kembali kepada konsepsi Nietzche dan pernyataan Harun Nasution di atas, bahwa beragam dan banyaknya informasi yang diterima oleh seorang santri tentang suatu perkara, maka hal itu akan menjadikan mereka lebih inklusif terhadap pendapat-pendapat lain. Keterbukaan ini tidak hanya di bidang fikih saja, tetapi juga di seluruh kehidupannya, karena pendapat-pendapat tersebut telah mengajarkan keanekaragaman pendapat di dalam Islam.

\footnotetext{
30 Suteja, "Orientasi Pembelajaran Kitab Fiqh di Pesantren Tradisional/Salafi”, makalah diakses dari http://www.scribd.com/doc/27638624/OreintasiPembelajaran-Kitab-Fiqh-Di-Pesantren-TradisionalSalafi

${ }^{31}$ Sahal Mahfud, Nuansa Fikih Sosial, (Yogyakarta: Elkis, 1994), 47.
} 
Sebaliknya, bila khazanah pemikiran fikih hanya terpaku kepada salah satu mazhab tertentu, justru hal ini akan berpotensi memunculkan fanatisisme di kalangan santri dan ketertutupan terhadap pendapat yang ada di luarnya. Akibat yang lebih besar, pandangan seperti ini justru dapat mengarahkan seseorang kepada klaim kebenaran terhadap suatu pendapat tertentu, yang secara praktis sangat ditentang oleh keempat imam mazhab fikih. Lebih jauh lagi, pandangan seperti ini dapat membawa perbaikan bagi kondisi keberagamaan di Indonesia, untuk lebih mengedepankan sikap-sikap toleransi, saling menghormati pendapat dan keyakinan orang lain, serta adanya keterbukaan untuk selalu berdialog dalam menyelesaikan masalah dan mencari solusi terbaik atas sebuah permasalahan. Dengan mengembangkan nilai-nilai keberagaman dan pluralitas tersebut, harapan bahwa nilai-nilai kesantrian yang selama ini tumbuh dapat dijadikan nilai universal menuju Indonesia ke depan, sebagaimana yang pernah diidealkan oleh Nurcholis Madjid. ${ }^{32}$

Secara praktik, perubahan kurikulum pembelajaran fikih ini dapat dimulai dari santri-santri senior yang telah memiliki cukup banyak amunisi untuk memahami fikih secara komprehensif. Selain telah memiliki dasar dalam menjalankan aktifitas keagamaan sehari-hari dari suatu mazhab tertentu, Syafi'iyah misalnya, para santri senior juga telah lebih mampu membaca karya-karya klasik yang lebih berat dan besar. Dalam hal ini, metode berjenjang dapat pula dilakukan secara horizontal, yaitu dengan perluasan materi pelajaran dari khazanah fikih Islam yang telah diwariskan oleh para ulama terdahulu.

\footnotetext{
32 Nurcholis Madjid, Tradisi Islam: Peran dan Fungsinya dalam Pembangunan di Indonesia, (Jakarta: Paramadina, 1997), 61
}

\section{E. PENUTUP}

Dari beberapa uraian di atas, ada beberapa hal yang penting untuk menjadi perhatian di dalam makalah ini, di antaranya adalah:

Pertama, sebagai sebuah subkultur, pesantren telah mampu menumbuhkan sikap keberagamaan khas, baik di lingkungan pesantren ataupun bagi lingkungan yang ada di sekitarnya. Hal ini menjadi sebuah modalitas bagi pesantren untuk lebih mengembangkan lagi apa yang telah dimilikinya untuk lebih baik dan terlibat aktif dalam perubahan sosial kemasyarakatan di Indonesia.

Kedua, secara historis, perubahan dan pembaruan pesantren telah terjadi di Indonesia sebagai upaya untuk merespon perubahan dan kemajuan zaman. Dalam konteks sistem pendidikan, hal ini setidaknya yang telah dipelopori oleh pesantren Tebu Ireng, yang memasukkan sistem pendidikan umum.

Ketiga, dalam pembelajaran fikih, pesantren perlu mengembangkan lagi untuk mendapatkan hasil yang lebih maksimal. Bila selama ini fikih yang diajarkan pesantren, terutama pesantren salaf, lebih berorientasi kepada mazhab Syafii, maka pada masa yang akan datang perlu pula untuk mempertimbangkan khazanah pemikiran fikih yang lebih luas dengan menjangkau, minimal empat aliran fikih, yang dikenal dalam Islam. Hal ini menjadi penting mengingat semakin banyaknya informasi atau pendapat yang diterima oleh kalangan santri tentang khazanah hukum Islam, hal ini dapat menumbuhkan sikap toleransi dan saling menghormati pendapat orang lain. Secara lebih luas, hal ini dapat menumbuhkan sikap toleransi bagi penduduk Indonesia yang beragama Islam. 


\section{DAFTAR PUSTAKA}

Abdurrahman Wahid, Islam Kosmopolitas: Nilai-nilai Indonesia dan Transformasi Kebudayaan. Jakarta: Wahid Institute, 2007.

Ahmad El Chumaedy, "Membongkar Tradisionalisme Pendidikan Pesantren; "Sebuah Pilihan Sejarah", 06 Oktober 2002 , searchengines.com/achumaedy.html

Azyumardi Azra, Dari Surau ke Sekolah dan Pesantren: Peluang dan Tantangan dalam Era Globalisasi dan Otonomi Daerah, Makalah Semiloka "Pesantren Bersejarah di Sumatera Barat" Bukittinggi, 17-19 Januari, 2003.

Azyumardi Azra dan Dina Afriyanti, Pesantren And Madrasa: Modernization Of Indonesian Muslim Society, makalah pada Workshop on Madrasa, Modernity and Islamic Education, Boston University, CURA, 6-7 Mei 2005

A. Setyo Wibowo, "Pencerahan di Mata Kant dan Nietzsche: Menjadi Dewasa dan Rekonyal", dalam Jurnal Diskursus, Vol. 8, No. 1, April 2009

A. Setyo Wibowo, Gaya Filasafat Nietzsche. Yogyakarta: Galang Press, 2004.

"Dampak Perubahan Orientasi Pondok Pesantren Terhadap Masyarakat", Rabu, 24 September 2008, diakses dari www.pondokpesantren.net

Habib Chirzin, Agama dan Ilmu Pengetahuan, dalam Dawam Rahardjo (ed.), Pesantren dan Pembangunan. Jakarta: LP3ES, 1995, cet. V

Jufri Dolong, Mengembangkan (Potensi) Pesantren, Kamis, 13 November 2008. Artikel diakses dari http://www.pondokpesantren.net/
Karel Steenbrink, Pesantren, Madrasah, Sekolah: Pendidikan Islam dalam Kurun Moderen, (Jakarta: LP3ES, 1994

Martin van Bruissen, "Pesantren dan Kitab Kuning”, dalam Jurnal Ulumul Qur'an, vol. III, No. 4 tahun 1992

Mulyadi J. Amalik, Pesantren, Pendidikan Islam Khas Indonesia (2), 18 November 2008, diakses dari www.kabarindonesia.com

Mochtar Buchari, Pendidikan Islam di Indonesia: Problem Masa Kini dan Perspektif Masa Depan, dalam Muntaha Azhari dan Abdul Mu'in (ed.), Islam Indonesia Menatap Masa Depan, (Jakarta: P3M, 1989

M. Dawam Rahardjo, Kehidupan Pemuda Santri: Penglihatan dari Jendela Pesantren Pabelan, dalam M. Dawam Rahardjo (ed.), Pesantren dan Pembangunan. Jakarta: LP3ES, 1995, cet. V

Nurcholis Madjid, Tradisi Islam: Peran dan Fungsinya dalam Pembangunan di Indonesia, (Jakarta: Paramadina, 1997.

Ronald Lukens Bull, A Peaceful Jihad: Negotiating Identity and Modernity in Muslim Java. MacMillan: Palgrave, 2005.

"Reinventing Kitab Kuning dalam Tradisi Pesantren", 10 Agustus 2008. Artikel dimuat dalam Jurnal al-Mighrab, Pekapontren Depag RI, Agustus 2008, diakses dari http://abdullahubaid.blogspot.com/2008/08/pesantrendan-kitab-kuning-adalah-dua.html.

Syafi'i Ahmadi, Pendidikan Islam pada Masa Orde Lama, dalam Abuddin Nata, Kapita Selekta Pendidikan Islam (Bandung: Angkasa, 2003.

Suteja, "Orientasi Pembelajaran Kitab Fiqh di Pesantren Tradisional/Salafi”, makalah diakses dari http://www.scribd.com/doc/27638624/O 
reintasi-Pembelajaran-Kitab-Fiqh-DiPesantren-Tradisional-Salafi

Sahal Mahfud, Nuansa Fikih Sosial. Yogyakarta: Elkis, 1994.

Zamakhsyari Dhofier, Tradisi Pesantren: Studi Tentang Pandangan Hidup Kyai, (Jakarta: LP3ES, 1982 